\title{
11. Identity and identification: Aboriginality from the Spanish Civil War to the French Ghettos
}

\section{VANESSA CASTEJON}

Postcolonial studies, Indigenous politics, Aboriginal self-determination, Aboriginal claims in the United Nations, the image of Aboriginal people in France: these are the topics I have studied in the last 12 years. I have come to realise that I have also been researching my own history. I am not saying my story is part of Indigenous history - I am very far from indigenous: I am a product of exile. I am from nowhere, my parents even had Nansen passports for apatrids and refugees (they have always said they had apatrid passports only, as if their country had completely disappeared for them). I am from various places with different identities fighting all the time to define me. Without my knowing it, this conflict has led me to researching Aboriginal identity.

In this chapter, I want to ask whether those of us who are non-Indigenous academics looking at Indigenous issues, are using our research as part of our own unconscious quest for identity. I seek to explore the subjectivity of my work as an historian, my lie in wanting to tell 'the truth'. As the French sociologist Romain Pudal writes, 'Not many (academics) are ready to admit, and even less analyze, the intimate relationship they have with their subject of research or with the writing of their colleagues.' ${ }^{1}$ Here, I want to take up his challenge in an attempt at ego-history, ${ }^{2}$ and consider my intimate relations with the subject of my research - Aboriginal politics and identity. Because of who I am, this chapter is a meditation on the cultural transfers between Aboriginal Australia, the Spanish Civil War and the French ghettos.

1 Pudal 2004: 186.

2 Pierre Nora created this genre in the 1980s; he asked historians to apply the methods of history to their own story. 


\section{Being French and Spanish in Australia}

My first identity was, I thought, French. I was born in France and I never wondered about my identity, I was French and that was it. I grew up in what is called in France a 'red suburb' (red because most of the cities there were and still are communist), the '9-3', a ghetto for immigrants and poor French people. I grew up in one of those cities where French rap was born, where riots took place in 2005. I was the 'French' girl in the class.

In the mid 1990s, on the day I asked for a birth certificate to apply for a grant to study Feminism in Australia for my PhD, I discovered I was born Spanish and my parents had changed my nationality to French only when I was 12 . It was an identity shock. I was reading Sally Morgan's My Place (1987) at the time and this identification is the reason why I switched to Aboriginal politics.

I realised, at that time, that I had not always been French but I really discovered I was French in Australia a few years later, during a long stay there. In France nobody asks where you are from, it is a sort of taboo question as it implies that you might not be French. It is even ruder in the area where I was born, in that 'red suburb', that ghetto. If political correctness existed in France, it definitely would be politically incorrect to ask this question. In Australia, it is quite different. I have travelled extensively since I was 12 and nowhere else have people asked me so many times where I was from. Everybody asked me that question in Australia: I used to begin by saying that I was born and have always lived in France and my mother tongue was French. People would say: 'so you are French'. Then I used to say: 'both my parents are Spanish', and they would say: 'then you are Spanish'. I did not have the choice, people wanted to define my identity because I was not doing it. I had to think about it, find a way to define myself against imposed definitions at a time I was also studying Aboriginal politics at Monash University's Centre for Australian Indigenous Studies, working on how Aboriginal people had to define themselves against imposed definitions.

Years later, in July 2008, I attended a conference entitled 'Myth, Memory and History' at the Centre for Australian Studies in Barcelona. On a sunny morning there, as I was speaking to a very good friend who was also researching Aboriginal identity, I told her about my family. I told her that my anarchist uncle's father was part of the Republican government in Exile - he was, I said, part of the Aboriginal Provisional Government. I suddenly saw the link between my family history and why I was studying Aboriginal politics.

I realised I had always known about this link. 'Retroactive clues' began to appear. I had dedicated my PhD thesis on Aboriginal political claims and identity 'to my parents and family who have always wanted to believe in another 
future'. I was inventing a link between Aboriginal self-determination and sovereignty and my family's anarchism, its fight against Franco's regime. Even in Aboriginal politics, I wanted to find links with the extreme left. The Aboriginal Provisional Government fascinated me. I have always idealised Gary Foley and his revolutionary attitude - I remember a picture of him with a Keffieh - and I also admired the Black Panthers. I remember Isabel Coe calling young activists 'warriors' at the tent embassy in Sydney in 2000. After my PhD, I began to be interested in the Working Group on Indigenous Peoples at the UN, the creation of a global identity to contain all the indigenous identities. Indigeneity made in Geneva. Perhaps in my quest for Aboriginality I wanted to see if something could bring together all my own identities.

\section{Aboriginal politics and the Spanish civil war}

Is it possible to compare the road towards post-colonialism in Australia as embodied in Aboriginal 'liberation movements' with the civil war in Spain? Ella Shohat sees forced exile as a part of post-colonialism, in that it is a 'breakingoff with the imperial centre' ${ }^{3}$ I need to explore this idea. In the late 1930s, my grandfather initiated an anarchist community in Aragon. They were trying to establish something free of domination, a fair society with no chief. During the years of the conflict (1936-1939) my grandmother committed suicide, apparently because of threats from the communists (it is difficult to know more about it as my dad was four at that time and I never met my grandparents). She first tried to kill herself with her two children but a neighbour saved the three of them from gas. My grandfather was at the front. My great-grandmother also committed suicide. My father and his sister were taken away. My aunt, who was eight, had to work as a maid and my dad was sent from one member of the family to the other and then to a Jesuit orphanage until he managed, when he was 15, to come illegally to France to 'meet' his dad who was in exile.

My mum was forced into exile with her parents and sister in February 1939, along with 500,000 other Republicans during what is known as 'La Retirada'. My mother's family left everything behind and crossed the border with one suitcase. They were put in what were called 'concentration camps' in France. My grandfather, as he arrived there first, used to sleep in a hole in the sand and eat only a sardine a day. 


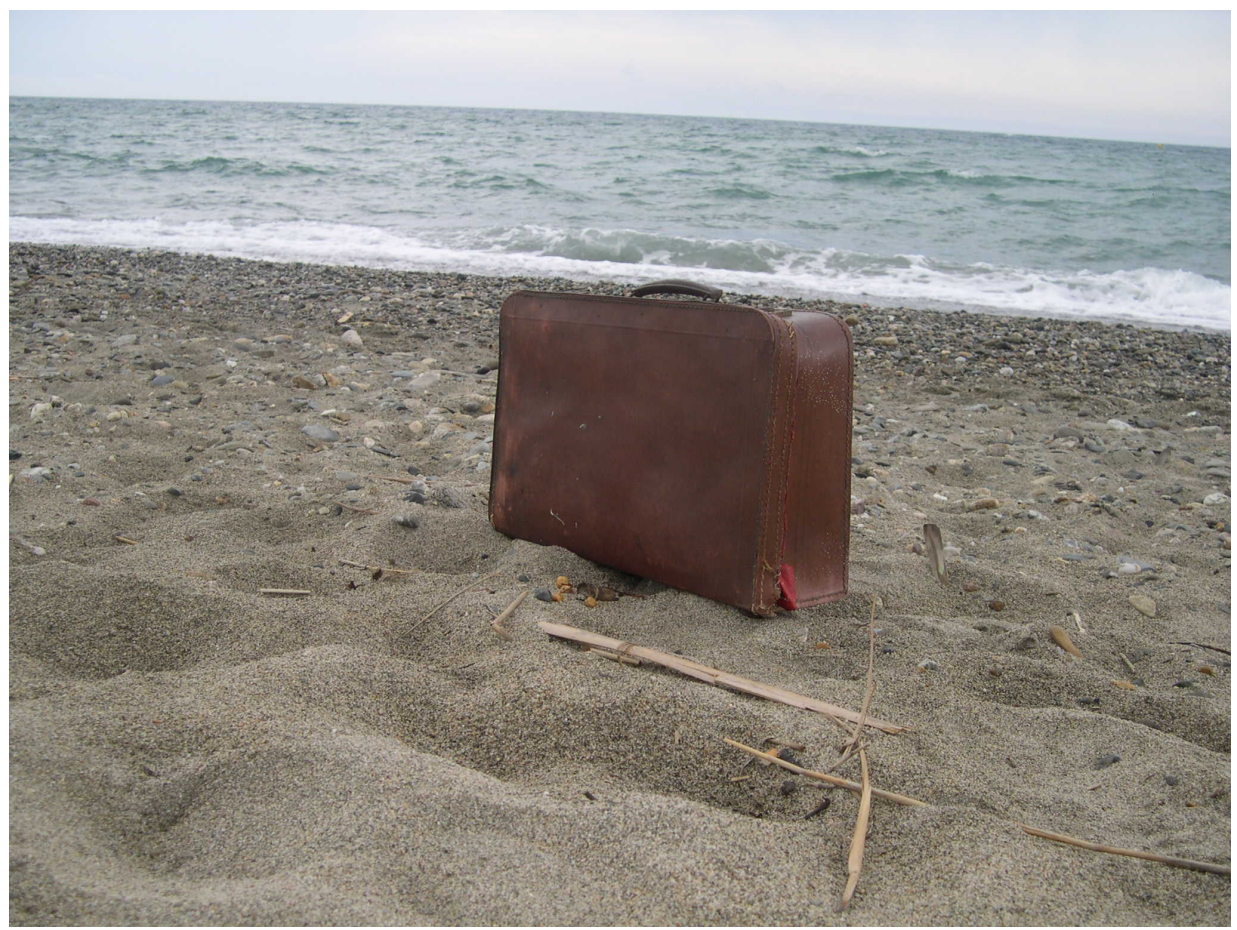

Fig 1. The suitcase my mother's family arrived with on the beach of Argeles where the refugee camp was located

Until the 1950s, my mother says her family believed that they would ultimately go back to Spain. She remembers the time when they suddenly realised they would be 'displaced' forever; they would 'have to become French', dig new roots.

They ultimately did become French. Not on paper though, they are still Spanish today and they had remained refugees/ apatrids with Nansen passports until Franco's death in 1975. They became so French that they did not want their children to be Spanish. I had to learn Spanish at university because my family did not teach me Spanish or Catalan at home.

In 2004, in desperate need to 'link-up' with my Spanish self, with my roots, I wrote a letter to the Spanish consulate to explain that I was the daughter of two persons who were forced into exile after the Spanish civil war. I was given Spanish nationality in less than one month. It was about recognition and re-appropriation. My family, who actually dispossessed me from my Spanish identity to protect me, was puzzled by this choice. My mother ended up being proud of it but my dad still does not understand why I should want to be 
anything other than French. Two years later, my son was born and he was born French and Spanish. My son's name is Paco partly because it is the short name for François in Spanish (François means 'French' in old French).

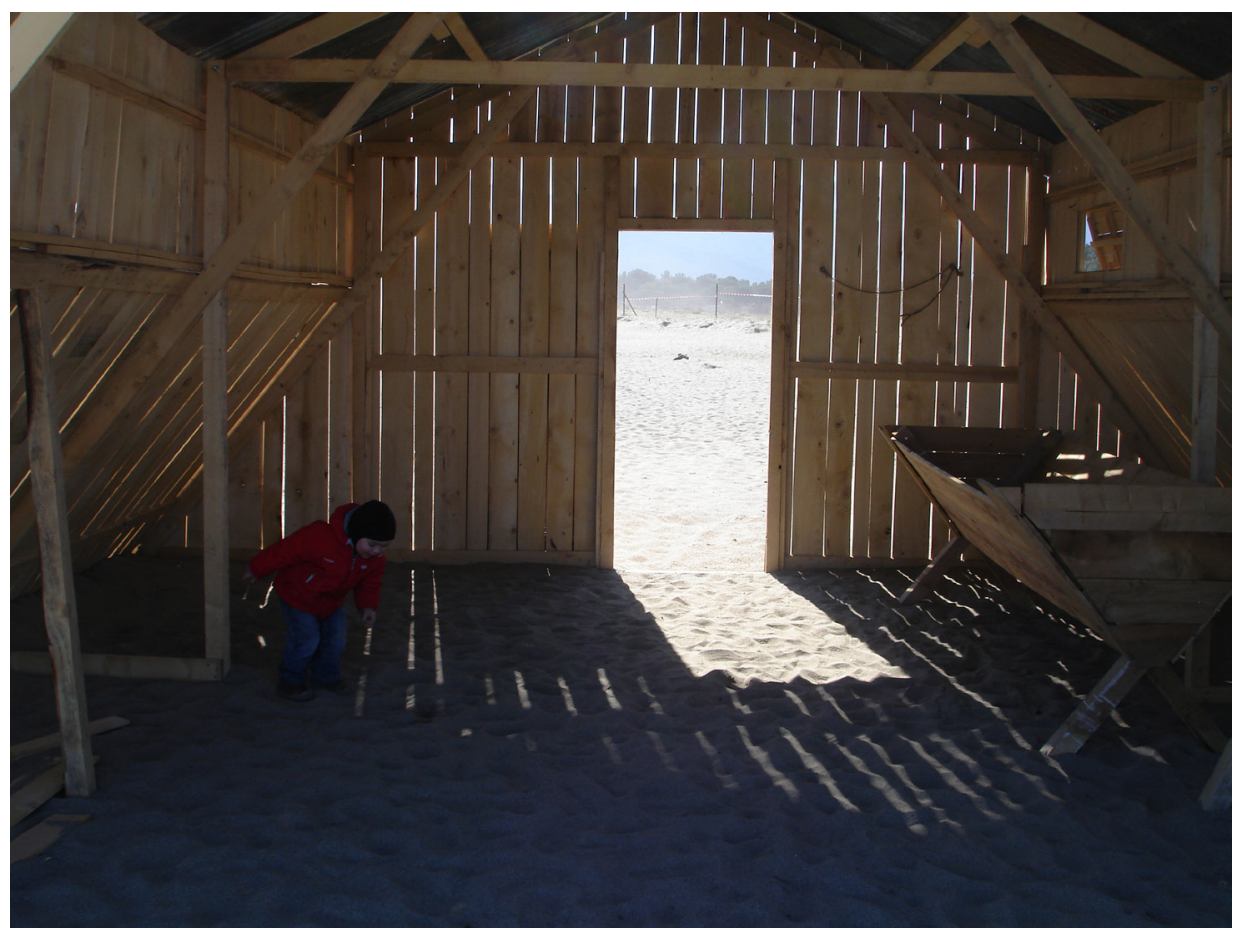

Fig 2. My son playing in a replica refugee 'house', Argeles beach, February 2009

I can see so many connections between my family history and my interest in Australian Aboriginal politics and identity. Both my parents were force into exile. I guess this is the origin of my interest in the power of the government on children, my interest in the Stolen Generations, and in assimilation and racism as well. Perhaps I unconsciously assimilated what I thought were Aboriginal communities with my family history, my grandfather's desire for a stateless society. Maybe I also assimilated Franco's coup and the reactions to it with the power stolen from Aboriginal people and their sovereignty claims. ${ }^{4} \mathrm{My}$ interest in displaced populations and the power of the government in shaping identity relates closely to my family's history. My family did not tell me of my Spanish origins. They hid the truth; they lied to protect us, just as Sally Morgan's parents did in her classic autobiographical novel, My Place. ${ }^{5}$ The experience of

4 Reynolds 1996: 136-154.

Morgan 1987. 
assimilation was all around me, and I pursued it in my interest in Aboriginal identity. In a more general context, I see links between the two histories, both in oppression and in reconciliation. Since December 2008, the Spanish government has been giving Spanish nationality to all the descendants of refugees who ask for it $^{6}$ and there has been a kind of apology in France as well, in the region where some of the concentration camps were (the president of the region thanked the Republicans during the celebrations of the 70th anniversary, in February 2009). ${ }^{7}$

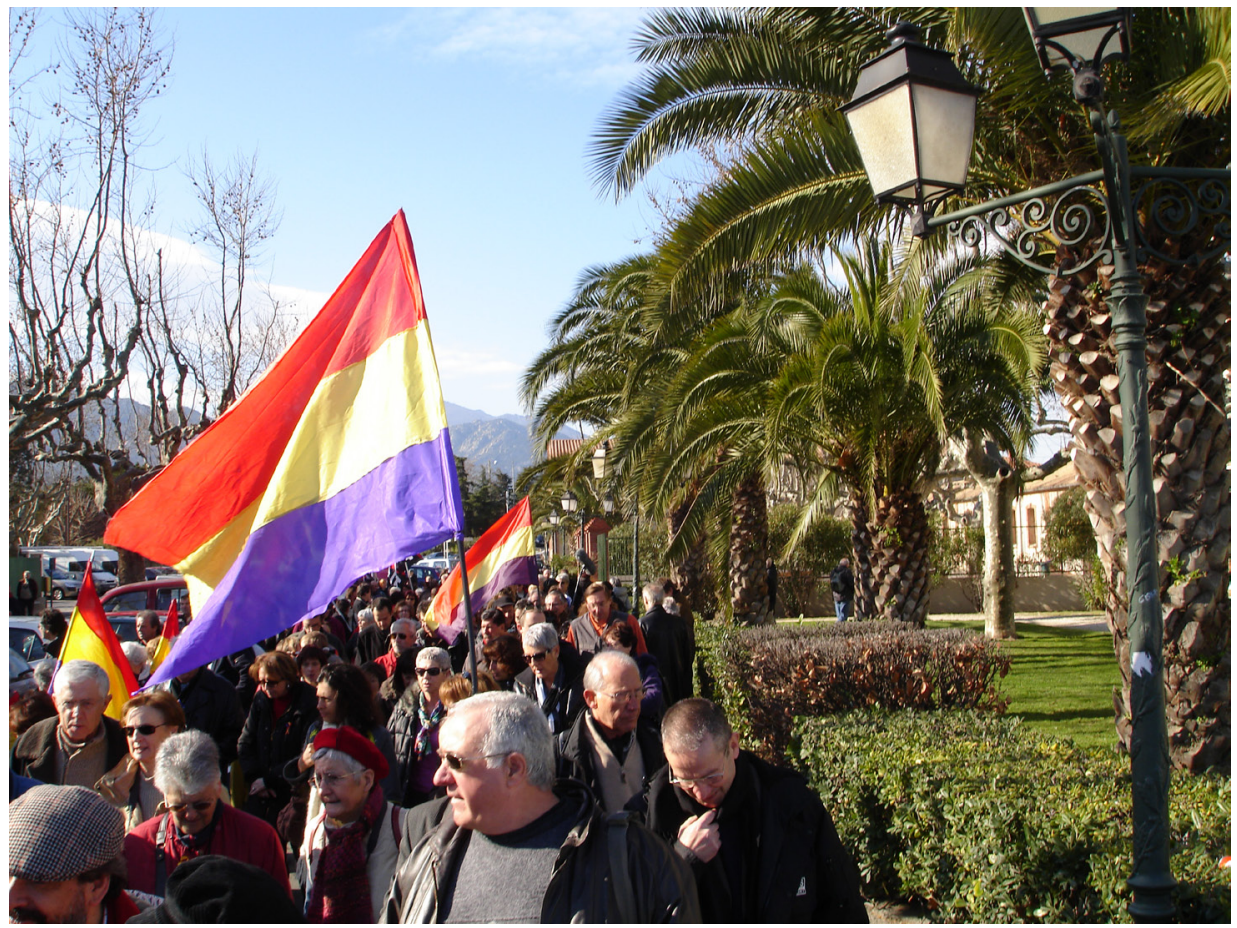

Fig 3. The 70th anniversary of 'La Retirada' and my father with the republican flag

\section{Denial and pride in a French ghetto}

If part of my identity is rooted in anarchism and exile, the other part is rooted in the suburb, the ghetto, the '9-3', where I grew up. I learnt the importance of this identity again in Australia, when I taught a class at Monash University entitled 'the ethnography of French Hip Hop culture'. The '9-3' used to be the French department No 93, the Seine-Saint-Denis, but a new clear identity arose a few years ago and it is now called ' $9-3$ ' by the generation who wants to 'belong'.

6 Historical Memory Law, 28 December 2008, available at: <http://leymemoria.mjusticia.es> for the descendants of Spanish Nationals involved in the Civil War and International Brigade Volunteers.

7 Frêche 2009: 3. 
Children of displaced people often build a new identity where they grow up, something they can relate to, keeping a bit of the idealised loss of identity but creating a new mix.

Even though, like many second-generation immigrants in the '9-3', I claim my Spanishness, I am unable to say more than one correct sentence in Spanish. But I can speak 'Verlan', the French suburban dialect. The 9-3 is very diverse but it has a language (also used in other Parisian suburbs), its music, its dance and, in general, its art (graffiti, djing, slam, rap) as the French hip-hop culture was born there. A mix of cultures gave birth to a new one. I always thought that I had to hide this part of my identity because in France it is not glorious to be from that ghetto. I denied my suburbanity. I worked on having no accent (young people from the suburbs often have this typical, not to stay stereotypical accent). I refrained from using 'verlan'. I did not wear the expected clothes; I wanted to look Parisian. I was in a strong denial of that place where people were exploited, dominated because of assimilationist, still colonial, policies. These people called 'second-zone citizens'. These people called by high profile politicians 'sauvageons' ${ }^{8}$ (a mix of 'wild child' and 'savage'), or 'racaille' ('scum') who had to be given the Karcher treatment, ${ }^{10}$ a 'smelly', 'noisy' people 'living out from social security benefits'. ${ }^{11}$

It was not easy for me to be from there. I realise now that my interest in exclusion in Australia definitely comes from there. The 9-3 is the place in France where the link between the indigenous and the immigrant is the clearest. It is the place where the social but also the colonial 'split' is evident. Racism is apparent; the 9-3 is one of the places where the National Front (the French One Nation party) is very strong. The 'Far Right' and the extreme right have demonised the people from there by 'otherising' them. The Wikipedia definition for the word racaille, used by Nicolas Sarkozy in 2005, makes a link between 'race' and racaille, stating that the expression was purely racist. Le Pen, the head of the National Front, and extreme right websites call the people from the ghetto 'la racaille allogène', the 'non-Indigenous scum'. Here again, a vocabulary linked with my research.

A movement was born a few years ago, claiming recognition of the people from the 'ghetto' and it is called 'Les Indigènes de la République' (The Indigenous people of the Republic). It is in favour of a fight by the postcolonial peoples to build an autonomous political power. ${ }^{12}$ In the name of the movement, the Republic might be a reference to the common reproach of communautarism,

8 Jean-Pierre Chevenement, 9 March 1998.

9 Nicolas Sarkozy, Minister of the Interior, 25 October 2005.

10 Nicolas Sarkozy, 20 June 2005.

11 Jacques Chirac, 19 June 1991.

12 Khiari 2006: 100. 
people fencing themselves in their community, which would supposedly put the values of the French Republic in danger ... the solution being Integration. 'Les Indigènes de la République' is clearly fighting Integration as a policy. ${ }^{13}$ Some journalists and politicians see the movement as a danger. It is trying to create 'an anti-colonial identity' in reaction to the conflict ${ }^{14}$, just like the Aboriginal Provisional Government editing Aboriginal Passports and Birth Certificates and claiming the right to an Aboriginal State.

Just like the Aboriginal Provisional Government again, and like the Aboriginal Black Power in the late 1960s to early 1970s, les Indigènes de la République is not a real threat, it is only trying to make the problems visible. They are fighting invisibility outside the ghetto.

The forced invisibility is comparable to the situation of Aboriginal people: a few years ago, non Aboriginal Australians or even tourists could still say that had never met an Indigenous person. In France, people from small villages are afraid of the people from the ghettos, people they have never met or wanted to meet.

In France as well, racism is demonstrated by the absence of people from 'the ghetto', the 'cités', in the media. When they do appear on television or in the main newspapers the image of the descendants of immigrants in the suburbs is always full of stereotypes. They are seen as savages ('sauvageons' as they were called by minister Jean-Pierre Chevenement), burning cars, stealing, dealing drugs, destroying everything after demonstrations in Paris. The media and the 'non-suburbans', in general, do not see the people from the ghettos as victims but as oppressors, just like 'white Australians who see themselves as victims, struggling heroically against adversity, and those that place them as aggressors, forcing adversity onto others' ${ }^{15}$

Sometimes anthropologists or journalists enter the ghetto and the situation is the same as in the Aboriginal communities: people are often afraid to be treated like animals in a zoo, and it is often actually the case. ${ }^{16}$

Historians Pascal Blanchard and Nicolas Bancel say that 'the suburb' has become a terra incognita for the media, the films and the political speeches, where none would dare enter. ${ }^{17}$

It is my Terra (Australis?) incognita that I want people to know about through my work.

13 On anti-integrationism see Hajjat 2005: 46-53.

14 Khiari 2006: 103.

15 Curthoys 2003: 187.

16 A famous scene of the film La Haine, by Mathieu Kassovitz, one of the first films on the suburbs, shows the reaction of young people to the intrusion of journalists filming them from their car.

17 Blanchard and Bancel 1998: 187. 
The Great French Silence also applies to the 'suburbs'. The taboo history of the war in Algeria, for example, makes it difficult to link the problems of the suburbs with the colonial wars. Even the new Museum of Immigration in Paris does not stress these links. In February 2005, the French government passed a law to force teachers to stress the good aspects of colonisation (the President invalidated it a few months after). It is not only a white blindfold view of History; it is almost revisionist. The possibility of a collective memory is denied to the people from the ghetto. The 'suburbs' are not considered as a part of colonial history. It is not only a lack of recognition of their suffering but a rejection again, the denial of a possible common history. My denial of my 'suburbanity' ended in Australia. Partly because of my teaching on the French Hip-Hop culture, and partly because of my research, I discovered that I was very proud of being from there. If my blood and my innate feelings were Spanish, my soul was from the 9-3. I was not only French; I belonged to the 9-3. I became proud of being part of the excluded, of the Other, proud of this town, Bobigny, where I was born, where none would go for pleasure. ${ }^{18}$ This pride is something common to the people who feel they 'belong' to the '9-3', according to 'Grand Corps Malade', one of the best and well-known slammers, in a song on the suburbs entitled 'Je viens de là' (I come from there). ${ }^{19}$ This new identity was created as a reaction to discrimination and domination, just like Aboriginality, created out of many identities as a reaction to domination.

I also work by choice in the 9-3, in a university full of students who 'belong' (they say they 'represent'). I am now a spectator of the evolution of identity there. I have seen recently, for example, the appearance of a new word, used in some cases to define the people outside the suburbs: 'Babtou', the Verlan of 'Toubab' which used to mean 'the Whites' in French colonial Africa.

I am proud of being from this lively, bubbling, hybrid suburb, this post-colonial effervescence. I am very grateful to my research for this new awareness of who I am and my pride in being who I am. I became proud of being me thanks to Aboriginal politics, through an unconscious mix of discriminations, of displaced peoples who have survived, survived colonial policies and imposed definitions and it is now clear to me that the subject of research is never far from the researcher.

18 Desplechin and Darzacq 2006.

19 Video accessible on Dailymotion or YouTube, showing images and faces of the ' $9-3$ '. 


\section{References}

Blanchard, Pascal, Nicolas Bancel and Sandrine Lemaire 2005, La Fracture Coloniale, Editions La découverte, Paris.

Blanchard, Pascal and Nicolas Bancel 1998, De l'indigène à l'immigré, Gallimard, Paris.

Curthoys, Ann 2003, 'Constructing national histories', in Frontier Conflict, The Australian Experience, Bain Attwood and SG Foster (eds), National Museum of Australia, Canberra: 185-200.

Desplechin, Marie and Denis Darzacq, 2006, Bobigny Centre Ville, Actes Sud, Paris.

Frêche, Georges 2009, 'Merci aux républicains espagnols', special edition on La Retirada, L'Indépendant, 20 February 2009: 1-24.

Hajjat, Abdellali 2005, Immigration postcoloniale et mémoire, L'Harmattan, Paris.

Khiari, Sadri 2006, Pour une Politique de la Racaille, Immigrés, Indigènes et Jeunes de Banlieue, Les Editions Textuel, Paris.

Morgan, Sally 1987, My Place, Fremantle Arts Centre Place, Fremantle.

Noiriel, Gérard 2003, Penser avec, penser contre. Itinéraire d'un Historien, Belin, Paris.

Nora, Pierre 1987, Essais d'ego-histoire, NRF Gallimard, Paris.

Perraud, Antoine 2002, 'Du mépris du peuple à la menace populiste, entretien avec Emmanuel Todd', Télérama, 27 April 2002.

Pudal, Romain 2004, Review of 'Noiriel (Gérard)-Penser avec, penser contre. Itinéraire d'un historien', in 'Les Sciences sociales en situation coloniale', Revue d'Histoire des Sciences Humaines 10: Sciences Humaines Editions, 183186.

Reynolds, Henry 1996, Aboriginal Sovereignty, Allen \& Unwin, Sydney.

Shohat, Ella 2007, 'Notes sur le "post-colonial" (1992)'. Mouvements 51, September-October, accessed 10 May 2010: <http:/www.mouvements.info/ Notes-sur-le-post-colonial-1992.html> 